\title{
STUDY OF EXCITON HOPPING IN AIGaN EPILAYERS BY PHOTOLUMINESCENCE SPECTROSCOPY AND MONTE CARLO SIMULATION*
}

\author{
K. Kazlauskas ${ }^{\text {a }}$, G. Tamulaitis ${ }^{\text {a }}$, A. Žukauskas ${ }^{\text {a }}$, J. Mickevičius ${ }^{\text {b }}$, M.S. Shur ${ }^{\text {b }}$, \\ R.S. Qhalid Fareed ${ }^{\text {c }}$, J.P. Zhang ${ }^{\mathrm{c}}$, and R. Gaska ${ }^{\mathrm{c}}$ \\ ${ }^{a}$ Institute of Materials Science and Applied Research, Vilnius University, Saulètekio 9, LT-10222 Vilnius, Lithuania \\ ${ }^{\mathrm{b}}$ Department of ECE and CIE, Rensselaer Polytechnic Institute, Troy, NY 12180, USA \\ E-mail: juras.mickevicius@ff.vu.lt \\ ${ }^{c}$ Sensor Electronic Technology, Inc., Columbia, SC 29209, USA
}

Received 11 October 2005

\begin{abstract}
Ternary AlGaN alloys are very promising for production of light-emitting diodes and laser diodes operating in deep ultraviolet range. Achieving shorter emission wavelength requires incorporation of higher aluminium content, which is still a major technological problem due to poor quality of the high-Al-content epilayers. We report on a comparative study of AlGaN epilayers with the same aluminium content, but grown by using different techniques. The temperature dependences of photoluminescence peak and bandwidth were found to exhibit "anomalous" S-shaped and W-shaped behaviour, respectively, which are known as a signature of exciton hopping through localized states. To evaluate the potential profile of the localized states, Monte Carlo simulations have been performed. Fitting of the simulation results with experimental data revealed that the potential profile in both $\mathrm{AlGaN}$ epilayers can be characterized by two nearly equal fluctuation scales. Exciton hopping occurs within the potential fluctuations (dispersed on the first scale) in isolated regions with the average energy of the localized states dispersed on the second scale. Both scales were found to be almost independent of the growth techniques used. Correlation of this potential profile with the lifetimes measured using time-resolved photoluminescence and light-induced transient grating techniques is discussed.
\end{abstract}

Keywords: AlGaN, Monte Carlo simulation, exciton hopping

PACS: 78.55.Cr, 73.50.Gr, 78.47.+p

\section{Introduction}

Wide-band-gap III-nitrides have been widely investigated over the past few years as prospective materials for development of deep ultraviolet (UV) lightemitting diodes (LEDs) and laser diodes. A huge interest in these devices was inspired by their possible applications in excitation of proteins and detection of hazardous biological agents, air and water purification, and high-density optical data storage. Development of efficient deep-UV LEDs for these applications requires high-quality AlGaN epilayers. Recently, the quality of epilayers has been significantly improved by introducing an additional buffer-layer grown by migration enhanced metal-organic chemical vapour deposition $\left(\mathrm{MEMOCVD}^{\mathrm{TM}}\right)$ technique [1].

\footnotetext{
* The report presented at the 36th Lithuanian National Physics Conference, 16-18 June 2005, Vilnius, Lithuania.
}

In this work, optical properties of AlGaN epilayers deposited on buffer layers grown by different techniques are compared. Samples are investigated by using quasi-steady-state and time-resolved (TR) photoluminescence (PL) spectroscopy, and light-induced transient grating (LITG) technique. The band potential profile was quantified by simulating the temperature dynamics of the PL linewidth obtained experimentally.

\section{Experimental}

AlGaN epilayers with a similar molar fraction of aluminium ( $26 \%)$, but grown by using different techniques were studied. Both samples were grown on sapphire substrate with $200 \AA$ A-thick AlN buffer layer, which was deposited by conventional low-pressure metal-organic chemical vapour deposition (MOCVD) for sample $S 1$ and by migration enhanced MOCVD 
$\left(\mathrm{MEMOCVD}^{\mathrm{TM}}\right.$ ) [1] technique for sample $S 2$. An additional dislocation-filtering $\mathrm{AlN} / \mathrm{AlGaN}$ superlattice was inserted in the buffer layer of sample $S 2$.

The PL spectra of the samples under quasi-steadystate conditions were studied by using the 5 th harmonic of a Q-switched YAG:Nd laser (excitation wavelength $213 \mathrm{~nm}$, pulse duration $4 \mathrm{~ns}$ ). The sample luminescence was collected and analyzed by using a TRIAX 550 spectrometer and a UV-enhanced intensified CCD camera. A closed cycle helium cryo-system was used for the temperature-dependent measurements in the range from 10 to $300 \mathrm{~K}$.

In TRPL experiments, the AlGaN epilayers were excited by the 5 th harmonic $(213 \mathrm{~nm})$ of the mode-locked YAG:Nd laser radiation (pulse duration $20 \mathrm{ps}$ ). The sample emission was analyzed by Hamamatsu streak camera with time resolution of 2 ps.

In the LITG experiments, two beams of the 4th harmonic $(266 \mathrm{~nm})$ of the mode-locked YAG:Nd laser radiation overlapped at the sample surface and created a thin grating due to the band-to-band excitation of the AlGaN epilayers. Delayed pulses of the 2 nd harmonic $(532 \mathrm{~nm})$ probed the decay of the induced grating. Recombination of the nonequilibrium carriers and their diffusion, which tends to homogenize the carrier distribution, are two main processes causing the grating decay. Provided that the surface recombination is insignificant, the grating decay time $\tau_{\mathrm{G}}$ is related to the carrier lifetime $\tau_{\mathrm{R}}$ and the ambipolar diffusion coefficient $D_{\mathrm{a}}$ as [2]

$$
\frac{1}{\tau_{\mathrm{G}}}=\frac{1}{\tau_{\mathrm{R}}}+\frac{4 \pi^{2} D_{\mathrm{a}}}{\Lambda^{2}} .
$$

At sufficiently large grating spacing $\Lambda$ the diffusion term can be neglected in Eq. (1) and the grating decay time provides a good estimate of the carrier lifetime.

\section{Results and discussion}

The temperature evolution of the PL spectra for both AlGaN samples is shown in Fig. 1. The peak position of the main PL band ( $4.0 \mathrm{eV}$ at low temperatures) is very similar in both samples. Additional peaks at the lower energy side are distanced $\sim 100$ and $\sim 200 \mathrm{meV}$ from the main peak and can be attributed to the phonon replicas of the main band.

As the temperature is increased, the band peak shows "anomalous" behaviour: it slightly redshifts at low temperatures, blueshifts in the range from 60 to $140 \mathrm{~K}$, and redshifts again at higher temperatures. The

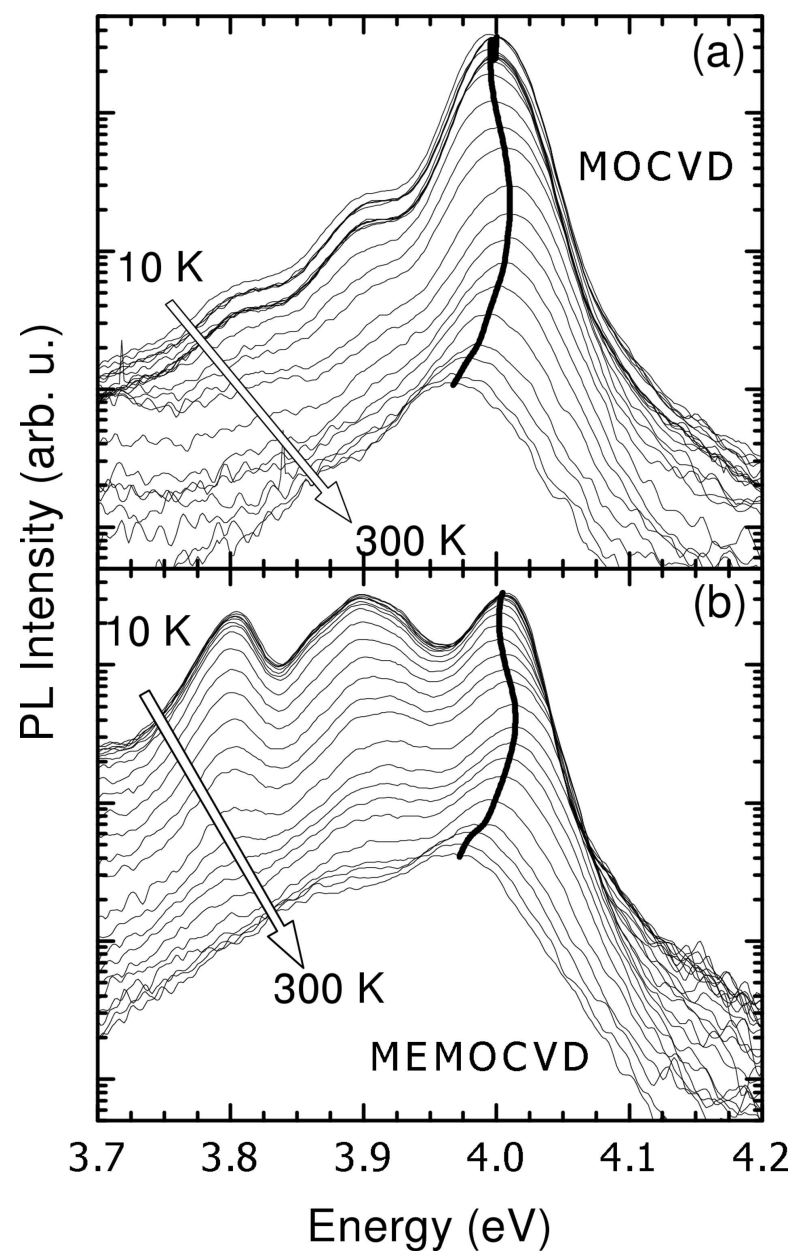

Fig. 1. Temperature evolution of PL spectrum in two AlGaN epilayers with buffer layers grown by (a) conventional MOCVD and (b) MEMOCVD ${ }^{\mathrm{TM}}$.

temperature dependence of the linewidth has a nonmonotonous W-shape (see Fig. 2). Such behaviour is well known as a signature of exciton hopping through localized states $[3,4]$ and has been observed in $\mathrm{InGaN}$ [5-7], AlGaN [8-10], and AlInGaN [11-14].

To estimate the carrier lifetimes, the epilayers have been investigated by using the LITG and TRPL techniques. The results of LITG measurements are shown in Fig. 3. The grating decay can be fitted by using the single exponential function as shown by the solid lines in Fig. 3. The grating decay time provides a good approximation for the carrier lifetime, since the grating spacing in our experiments has been selected large enough for carrier diffusion to be neglected. The estimated values were found to be $30 \mathrm{ps}$ and $190 \mathrm{ps}$ for the samples $S 1$ and $S 2$, respectively.

The results of time-resolved PL spectroscopy are shown in Fig. 4. As it has been predicted by theory [15], the decay is clearly non-exponential. Thus the carrier lifetimes cannot be determined unambigu- 


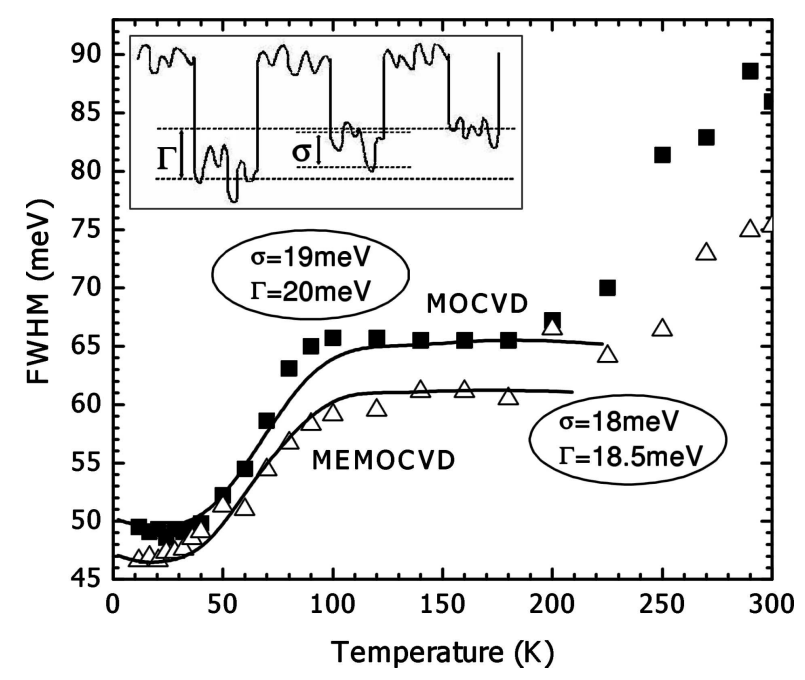

Fig. 2. The PL bandwidth dependence on the temperature for two AlGaN epilayers. Lines show results obtained by Monte Carlo simulation of exciton hopping within a double-scaled potential profile with fluctuations inside isolated regions $(\sigma)$ and distribution of the average localization energy $(\Gamma)$ in these regions (see inset).

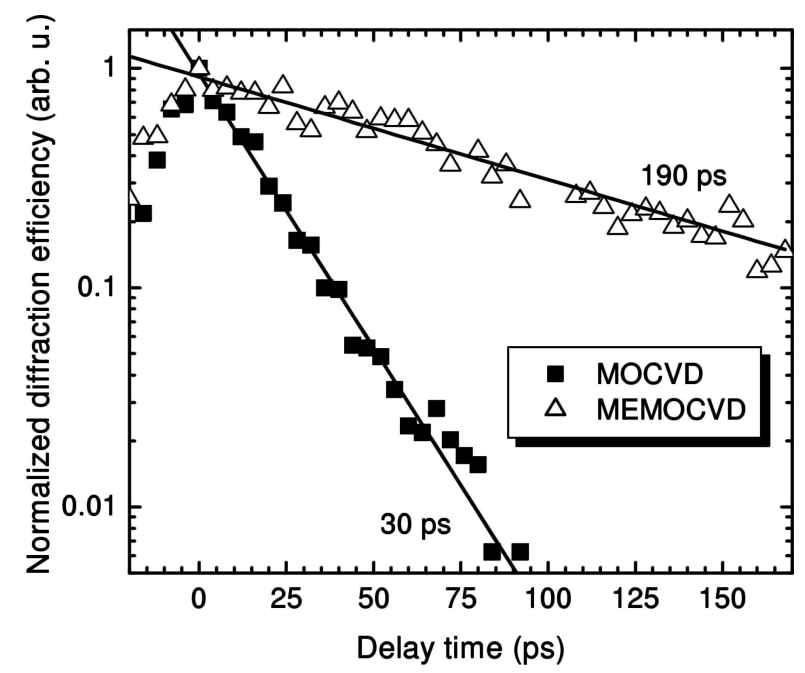

Fig. 3. LITG decay in MOCVD and MEMOCVD ${ }^{\mathrm{TM}}$-grown $\mathrm{AlGaN}$ epilayers for the grating period of $7.7 \mu \mathrm{m}$. Carrier lifetimes estimated by fitting the decay transients with single exponents (lines) are indicated.

ously. To relate the TRPL results with the LITG results, the PL decay curves were fitted by using biexponential function with decay times taken to be equal to the LITG carrier lifetime and a half of it:

$$
I_{\mathrm{LUM}}(t) \propto A_{1} \exp \left(-\frac{t}{\tau / 2}\right)+A_{2} \exp \left(-\frac{t}{\tau}\right)
$$

Such approach is reasonable, if we assume that the decay of the nonequilibrium carriers is dominated by the nonradiative recombination. Since the samples were unintentionally $n$-type doped, we neglected the equilibrium hole density. Thus, the luminescence intensity for

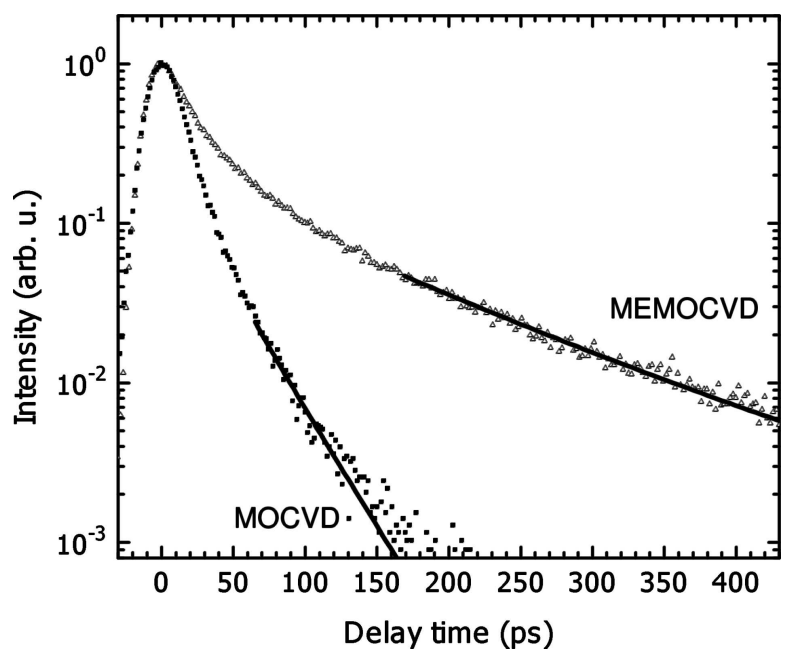

Fig. 4. PL decay kinetics (points) in two AlGaN samples. The solid lines show the best fit of the decay by using Eq. (2).

band-to-band transitions depends on the equilibrium, $n_{0}$, and nonequilibrium, $\Delta n$, electron densities:

$$
I_{\mathrm{LUM}} \propto \Delta n\left(\Delta n+n_{0}\right) .
$$

Bimolecular radiative recombination, stimulated emission, and carrier heating effects might influence the initial rapid decay of the carrier density $[15,16]$ (see Fig. 4). However, at later stages of the decay, these effects become less important resulting in the exponential decay of the nonequilibrium carrier density with the characteristic lifetime $\tau$. As seen from Eq. (3), the $I_{\mathrm{LUM}}$ decay in such conditions might be asymptotically described by exponents with the characteristic time, which depends on $\Delta n$. The PL decay time constant transforms from $\tau / 2$ for $\Delta n \gg n_{0}$ to $\tau$ for $\Delta n \ll n_{0}$.

The fits of experimental decay curves by using Eq. (2) are shown in Fig. 4 by solid lines. Except of the initial rapid decay, a good agreement between LITG and TRPL results was achieved. Most probably, the difference in the carrier lifetimes might be due either to the differences in the densities of nonradiative recombination centres or in the amplitude of the potential fluctuations, which prevent carriers from reaching those recombination centres. To distinguish between these two effects, temperature dependence of photoluminescence characteristics was measured and compared with the results obtained by Monte Carlo simulation of localized exciton hopping $[4,14]$. In the simulation, the excitons are hopping through the localized states randomly distributed in space. The energies of the localized states were assumed to have a Gaussian distribution with the standard deviation $\sigma$. The rate of the exciton hopping from a localized state $i$ to a state $j$ separated by the 
distance $R_{i j}$ was described by Miller-Abrahams expression

$$
\nu_{i j}=\nu_{0} \exp \left(-\frac{2 R_{i j}}{\alpha}-\frac{E_{j}-E_{i}+\left|E_{j}-E_{i}\right|}{2 k_{\mathrm{B}} T}\right),
$$

where $E_{i}$ and $E_{j}$ are the energies of the $i$ th and $j$ th states, respectively, $\alpha$ is the decay length of the exciton wave function, and $\nu_{0}$ is the attempt-to-escape frequency. For each exciton, one of the two possible events, either a hop to another state or radiative annihilation, was randomly selected by taking into account the rate of radiative recombination and all possible hopping rates described by Eq. (4). The energies of the localized states, at which the exciton recombined, were recorded to compile the emission spectrum.

The simulations performed on the single-scaled potential fluctuation profile failed to quantitatively describe the experimental dependences of the PL linewidth: the simulated values were considerably smaller than the measured ones. Additional line broadening was introduced by adopting the double-scaled potential fluctuation profile model (schematically shown in the inset of Fig. 2). According to this model, exciton hopping occurs through the potential fluctuations (on the scale $\sigma$ ) in isolated regions, possibly containing less aluminium. The average exciton energy in such individual regions is lower than in the rest of the epilayer and has another characteristic distribution scale, $\Gamma$. The results of the simulations are shown by the solid lines in Fig. 2. A good agreement between simulations and experimental results was obtained up to the $180 \mathrm{~K}$ temperature. A further increase of the linewidth is due to the extended states, which were not encompassed within this model.

The potential fluctuation scales were found to be very similar in both $\mathrm{AlGaN}$ epilayers, independently of the growth technique used: $\sigma=19 \mathrm{meV}, \Gamma=20 \mathrm{meV}$ in sample $S 1$ and $\sigma=18 \mathrm{meV}, \Gamma=18.5 \mathrm{meV}$ in sample $S 2$. Thus, the band potential profile is similar in both samples and, consequently, it should not cause the difference in carrier lifetimes. Therefore, we attribute the six-fold difference in carrier lifetimes in AlGaN epilayers under study to the different densities of nonradiative recombination centres.

\section{Conclusions}

Exciton hopping through localized states in AlGaN epilayers was revealed from the "anomalous" S- and W-shaped temperature dependences of the PL band peak and linewidth, respectively. Double-scaled potential profile model was used to quantitatively describe the potential fluctuations in the epilayers. In this model, localized states are randomly distributed on the scale $\sigma$ in the isolated low-potential regions with the average localization energy in these regions dispersed on the scale $\Gamma$. Both characteristic scales were estimated to be similar, $\sim(18-20) \mathrm{meV}$, in AlGaN epilayers with similar $\mathrm{Al}$ content. It is concluded that the difference in carrier lifetimes is due to the different densities of nonradiative recombination centres, which are influenced by the growth technique used. The MEMOCVD ${ }^{\mathrm{TM}}$ growth technique enabled an increase in carrier lifetime by a factor of 6 .

\section{Acknowledgements}

This material is based upon work supported by the National Science Foundation under Grant No. 0442259. Any opinions, findings, and conclusions or recommendations expressed in this material are those of the authors and do not necessarily reflect the views of the National Science Foundation. A partial support by the Lithuanian Science and Studies Foundation Program MODELITA at Vilnius University is acknowledged. One of the authors (G. T.) acknowledges the Lithuanian Ministry of Education and Science for his Fellowship.

\section{References}

[1] R.S.Q. Fareed, R. Jain, R. Gaska, M.S. Shur, J. Wu, W. Walukiewicz, and M.A. Khan, Appl. Phys. Lett. 84, 1892 (2004).

[2] A. Miller, in: Nonlinear Optics in Semiconductors II, Volume 59 (Semiconductors and Semimetals), eds. E. Garmire and A. Kost (Academic Press, New York, 1999) pp. 287, 292.

[3] D. Monroe, Phys. Rev. Lett. 54, 146 (1985).

[4] S.D. Baranovskii, R. Eichmann, and P. Thomas, Phys. Rev. B 58, 13081 (1998).

[5] P.G. Eliseev, P. Perlin, J. Lee, and M. Osinski, Appl. Phys. Lett. 71, 569 (1997).

[6] Y.-H. Cho, G.H. Gainer, A.J. Fisher, J.J. Song, S. Keller, U.K. Mishra, and S.P. DenBaars, Appl. Phys. Lett. 73, 1370 (1998).

[7] K. Kazlauskas, G. Tamulaitis, P. Pobedinskas, A. Žukauskas, M. Springis, C.-F. Huang, Y.-C. Cheng, and C.C. Yang, Phys. Rev. B 71, 085306 (2005).

[8] Y.-H. Cho, G.H. Gainer, J.B. Lam, J.J. Song, W. Yang, and W. Jhe, Phys. Rev. B 61, 7203 (2000).

[9] H.S. Kim, R.A. Mair, J. Li, J.Y. Lin, and H.X. Jiang, Appl. Phys. Lett. 76, 1252 (2000). 
[10] Y.-H. Cho, G.H. Gainer, J.B. Lam, J.J. Song, and W. Yang, Phys. Stat. Sol. A 188, 815 (2001).

[11] C.H. Chen, L.Y. Huang, Y.F. Chen, H.X. Jiang, and J.Y. Lin, Appl. Phys. Lett. 80, 1397 (2002).

[12] T. Wang, Y.H. Liu, Y.B. Lee, J.P. Ao, J. Bai, and S. Sakai, Appl. Phys. Lett. 81, 2508 (2002).

[13] K. Kazlauskas, G. Tamulaitis, A. Žukauskas, M.A. Khan, J.W. Yang J. Zhang, E. Kuokstis, G. Simin, M.S. Shur, R. Gaska, Appl. Phys. Lett. 82, 4501 (2003).
[14] K. Kazlauskas, G. Tamulaitis, A. Žukauskas, M.A. Khan, J.W. Yang, J. Zhang, G. Simin, M.S. Shur, and R. Gaska, Appl. Phys. Lett. 83, 3722 (2003).

[15] O. Brandt, H. Yang, and K.H. Ploog, Phys. Rev. B 54, R5215 (1996).

[16] S. Juršėnas, N. Kurilčik, G. Kurilčik, S. Miasojedovas, A. Žukauskas, T. Suski, P. Perlin, M. Lesczynski, P. Prystawko, and I. Grzegory, Appl. Phys. Lett. 85, 952 (2004).

\title{
EKSITONŲ ŠOKAVIMO AIGaN SLUOKSNIUOSE TYRIMAS FOTOLIUMINESCENCINE SPEKTROSKOPIJA IR MONTE KARLO MODELIAVIMU
}

\author{
K. Kazlauskas ${ }^{\text {a }}$, G. Tamulaitis ${ }^{\text {a }}$, A. Žukauskas ${ }^{\text {a }}$, J. Mickevičius ${ }^{\text {b }}$, M.S. Shur ${ }^{\text {b }}$, R.S. Qhalid Fareed ${ }^{\text {c }}$, J.P. Zhang ${ }^{\text {, }}$, \\ R. Gaska ${ }^{\mathrm{c}}$ \\ ${ }^{a}$ Vilniaus universitetas, Vilnius, Lietuva \\ ${ }^{\mathrm{b}}$ Rensselaer politechnikos institutas, Troja, Niujorko valst., JAV \\ ${ }^{\mathrm{c}}$ Sensor Electronic Technology, Kolumbija, Pietu Karolinos valst., JAV
}

\section{Santrauka}

Trinariai AlGaN dariniai yra perspektyvūs ultravioletinių šviestukų ir lazerių gamybai, tačiau didinant aliuminio kiekį iškyla didelès technologinès problemos, susijusios su AlGaN sluoksniu kokybe. Šiame darbe palygintos dviejų AlGaN epitaksinių sluoksnių, išaugintų skirtingais metodais, savybès. Sluoksniai yra charakterizuojami panaudojant fotoliuminescencijos, fotoliuminescencijos su laikine skyra ir indukuotų dinaminių gardelių metodikas. Išmatuotos fotoliuminescencijos juostos smailès ir pločio temperatūrinès priklausomybès yra anomalios $\mathrm{S}$ ir $\mathrm{W}$ formos. Tai parodo, kad žemoje temperatūroje sluoksniuose vyrauja eksitonų šokavimas per lokalias būsenas. Šis reiškinys buvo tyrinejjamas modeliuojant eksitonų šokavimą Monte Karlo metodu, derinant modeliavimo rezultatus su ekperimentiškai gautomis priklausomybèmis ir tokiu būdu nustatant potencialo profilį. Iš gautujų rezultatų paaiškejjo, kad potencialo profilis abiejuose AlGaN sluoksniuose gali būti kiekybiškai apibūdinamas tik panaudojus dvejopo mastelio fliuktuacijų modeli. Pagal toki modeli eksitonai šokuoja per lokalias būsenas, atsiradusias dèl potencialo fliuktuacijų su tam tikra dispersija žemesnio potencialo srityse su mažesniu nei vidutinis aliuminio kiekiu. Šių sričių vidutinè eksitono energija yra pasiskirsčiusi pagal kitą mastelį. Nustatytas potencialo profilis yra labai panašus abiejuose sluoksniuose, nepriklausomai nuo jų auginimo technologijos. Todèl eksperimentuose su laikine skyra gautą didelị krūvininkų gyvavimo trukmių skirtumą lemia nespindulinès rekombinacijos centrų tankio skirtumas, kuris atsiranda dèl nevienodų auginimo sąlygų. 